\title{
Da relação entre a autoridade espiritual e a autoridade secular no pensamento de Lutero
}

\author{
On the relation between the spiritual authority and \\ the secular authority in Luther's thought
}

\author{
Renato de Oliveira Pereira \\ Graduando do curso de Filosofia, Universidade Estadual Paulista - UNESP, Marília, SP, Brasil.
}

Resumo: Este trabalho visa apresentar de maneira introdutória como Lutero define os limites entre a autoridade espiritual e a autoridade secular. Ao buscar reformar a Igreja Católica Romana, Lutero defende que esta repasse à autoridade secular vários poderes adquiridos ilegalmente. Assim, o autor amplia o poder da autoridade secular e demonstra que a política é uma ocupação temporal. Porém, ao fazê-lo, Lutero enfatiza que a autoridade secular subordina-se à autoridade espiritual, já que a preocupação principal da teologia luterana é a possibilidade da salvação, o que faz a Espada ser apenas um meio necessário para tal finalidade devido à natureza decaída dos homens.

Palavras-chave: solifideísmo, autoridade secular, autoridade espiritual, igreja católica romana, reforma.

\begin{abstract}
This paper aims to show in an introductory way how Luther defines the limits between the spiritual authority and the secular authority. In seeking to reform the Roman Catholic Church, Luther argues that this transfer to the secular authority various powers acquired illegally. Thus, the author unleashes the power of secular authority and shows that politics is a temporal occupation. However, in doing so, Luther emphasizes that the secular authority subordinate to the spiritual authority, since the main concern of Lutheran theology is the possibility of salvation, which makes the Sword just a necessary means for this purpose because of the fallen nature of the men.
\end{abstract}

Keywords: solifideism, secular authority, spiritual authority, roman catholic church, reform. 


\section{Introdução}

Com o intuito de apresentar como Martinho Lutero (1483-1546) delineia os limites entre a autoridade espiritual e a autoridade secular, nossa análise terá como ponto de partida a obra de Quentin Skinner, As fundações do pensamento político moderno, com especial atenção para o capítulo 10, no qual Skinner trata especificamente de Lutero. Dois textos do reformador alemão foram utilizados como fonte primária para a análise, a saber, Da liberdade do cristão (1520) e o tratado Sobre a autoridade secular (1523). Para facilitar a discussão e exposição do tema, este trabalho foi dividido em três partes: na primeira, apresentaremos alguns aspectos principais da teologia de Lutero e o modo pelo qual ela vai exprimir consequências de cunho político. Na segunda parte, mostraremos como e por que Lutero recorreu aos governantes seculares para levar a cabo a Reforma da Igreja de Roma, bem como os problemas e as possibilidades dessa cooperação. Na terceira parte, enfim, trataremos da autoridade secular para mostrar que, na perspectiva de Lutero, seu fundamento é Deus e que, em decorrência disso, há funções e limites claros para os governantes seculares.

Para Lutero, existem dois reinos: o Reino de Deus e o Reino do Mundo. Enquanto o primeiro tem um governo espiritual e interior sob a jurisdição de Cristo, o segundo tem um governo secular e exterior dominado pela autoridade secular, pela Espada. Os cristãos pertencem ao Reino de Deus, enquanto os não-cristãos fazem parte do Reino do Mundo. Mas qual a diferença entre os dois reinos? Um cristão não tem nenhuma obrigação com relação ao Reino do Mundo? Para responder a tais questões, apresentaremos de maneira sucinta os pressupostos fundamentais da teologia luterana, reconstituindo sua formulação a partir de Skinner (1996). Tal consideração nos será útil porque Lutero tem por base as Sagradas Escrituras, de modo que a interpretação que o reformador alemão faz da Escritura constitui sua teologia, a qual vai servir de embasamento para as suas convicções políticas.

A teologia de Lutero exerce um papel tão significativo na formulação de seu pensamento político que Skinner (1996, p. 301), ao concluir o capítulo sobre o reformador alemão em As fundações do pensamento político moderno, afirma que "a palavra final de Lutero está baseada, sempre, na Palavra de Deus". Por outro lado, na introdução da tradução inglesa de Sobre a autoridade secular, Höpfl (2005, p. XIII) pondera que o reformador alemão

[...] trouxe para a reflexão política as preocupações de uma teologia altamente sofisticada. Mas trouxe muito mais coisas, que podem ou não ser coerentes com essa teologia, mas certamente são independentes dela.

De todo modo, compreender alguns dos pressupostos fundamentais da teologia luterana é importante para entendermos como nosso autor trata da relação entre o poder espiritual e o poder secular.

\section{Sola fide: "pela fé somente" - a doutrina da justificação de Lutero}

Ao contrário dos humanistas, que acreditavam que o homem tinha o poder e a capacidade de mudar o seu destino de acordo com a sua vontade, Lutero considerava o homem um ser indigno, decaído, pecador, mau, injusto, incapaz de transformar a sua realidade. Esse pessimismo em relação ao homem retoma, como nota Skinner (1996, p. 286), a concepção negativa que Santo Agostinho tem acerca da natureza humana. Tal posição representa uma ruptura com o pensamento tomista, que na época era preponderante na Igreja, e traz consigo uma consequência terrível para Lutero, qual seja, a impossibilidade da salvação. 
Lutero acreditava que a vontade humana, após a queda de Adão, houvesse se tornado mera escrava dos pecados ${ }^{1} \mathrm{e}$, portanto, tudo o que o homem faz nada mais é do que expressão de sua iniquidade, de seus pecados, de sua natureza decaída. Não é relevante o fato de o homem ser livre ou não, já que tudo aquilo que ele faz pensando ser virtuoso não é capaz de justificá-lo, isto é, de garantir sua salvação. O homem é, portanto, um ser impotente, diminuído ante a onipotência e grandiosidade do Criador.

Esta constatação, como aponta Skinner (1996, p. 289), levou o próprio Lutero a uma crise existencial profunda que teve como ápice seu ódio à palavra justiça, entendida apenas como a condenação de todos os pecadores, de todos os homens. Porém, ao analisar com mais clareza o Salmo 30, "liberta-me em tua justiça", Lutero tem a intuição que o levará a formular sua doutrina ultra-agostiniana da justificação, como relata Skinner (1996, p. 289, grifo nosso):

[...] subitamente ocorreu-lhe que o conceito de justiça divina poderia não se referir a Seus poderes punitivos, mas, antes, a Sua disposição a mostrar misericórdia ante os pecadores, e a justificá-los desse modo, libertando-os de sua injustiça.

A justificativa perante Deus não se dá, como queriam os medievais, mediante um processo gradativo no qual os pecados seriam eliminados. O homem é um ser imperfeito, o que implica no fato de que ele é, por si só, incapaz de não pecar ou de redimir os seus pecados. Nesse sentido, a salvação só é possível se o homem se voltar para Deus, e não para si próprio. O homem não pode alcançar a justiça através de suas obras. Ele só pode alcançá-la por meio da graça de Deus. Nas palavras de Skinner (1996, p. 290):

[Lutero] vê a justificação como uma consequência imediata da fides apprehensiva - de "uma fé que apreende e apropria", capacitando inesperadamente o pecador a captar por si mesmo a justiça de Cristo, de modo a tomar-se "uno com Cristo, tendo a mesma justiça que Ele" (p. 298; cf. ALTHAUS, 1966, p. 230). O resultado é uma ênfase extremamente forte na ideia de que a justiça do crente jamais é domestica - nunca é atingida, menos ainda merecida, por ele. Só pode ser-lhe extranea - uma "justiça estranha, instilada em nós sem nossas obras, pela graça somente" (p. 299). O fiel em qualquer ocasião é visto como simul justus et peccator - a um só tempo, pecador e justificado. Seus pecados jamais são apagados, mas sua fé garante que deixem de pesar contra ele.

Lutero conclui, portanto, que apenas a fé pode salvar o homem ${ }^{2}$ e tal fé nada mais é do que a crença na Palavra Divina revelada por Cristo. Segundo o reformador alemão, as Sagradas Escrituras são constituídas por dois tipos de palavras: (1) os mandamentos ou leis de Deus (Velho Testamento) e (2) a promessa ou o compromisso (Novo Testamento). "Os mandamentos", escreve Lutero (1998, p. 31, grifo nosso) em A liberdade do cristão (1520),

[...] nos ensinam e prescrevem todo tipo de boas obras, mas não é assim que se efetivam. Eles orientam, mas não ajudam; ensinam o que se deve fazer, mas não dão força para isso.

Ser imperfeito, o homem é incapaz de cumprir todas as leis de Deus, que são muitas e extremamente difíceis de obedecer. Como não é capaz de cumpri-las, o homem teme a condenação eterna.

No entanto, Lutero considera que esta constatação constitui a função pedagógica dos mandamentos. Ao propor uma série de leis rígidas que os homens não podem cumprir, Deus teria o objetivo de fazer o homem conhecer a sua natureza pecadora,

\footnotetext{
${ }^{1}$ Lutero define tal convicção em $A$ servidão da vontade, livro que escreveu em resposta à obra do humanista Erasmo de Roterdã denominada A liberdade da vontade (Cf. SKINNER, 1996, p. 286-7).

2 Daí o termo solifideísmo, que provém dos termos latinos sola fide, "pela fé somente" (Cf. SKINNER, 1996, p. 290).
} 
de maneira a descobrir-se como ser impotente. Nas palavras do próprio Lutero (1998, p. 31-33, § 8-9):

[Os mandamentos ou leis de Deus] só foram ordenados para que o ser humano veja neles a sua incapacidade de fazer o bem e aprenda a desesperançar-se consigo mesmo. Por isso, eles são chamados também de Velho Testamento, e pertencem todos ao Velho Testamento. Assim, o mandamento "Não cobiçarás", demonstra que todos somos pecadores e que ninguém é capaz de viver sem cobiçar, faça o que fizer. A partir disso, o ser humano aprende a desanimar-se consigo mesmo e a procurar ajuda noutro lugar, a fim de livrar-se da cobiça, cumprindo assim o mandamento por intermédio de um outro, já que ele sozinho não o consegue: portanto, todos os outros mandamentos também nos são impossíveis.

Nada que o homem encontre em si mesmo será suficiente para que ele se salve. Sentindo-se humilhado, ele é obrigado a buscar a sua salvação em algo exterior. É aí que entra a outra Palavra, isto é, a promessa de Deus revelada por Cristo: a salvação não exige que todos os mandamentos sejam cumpridos, pois só Deus, ser perfeito, seria capaz de fazê-lo. Não é, pois, o cumprimento dos mandamentos, tampouco a realização de obras externas - práticas como jejum e caridade, por exemplo - que dá ao homem a justificação perante Deus, mas somente a fé, já que Deus sintetizou todas as coisas nela: "crê em Cristo, pois nele te prometo toda a graça, justiça paz e liberdade. Se crês, já as tem, mas se não crês, então, nada tens". Nenhum tipo de obra pode se igualar à fé, pois todas as obras se referem às coisas exteriores, isto é, ao corpo, ao passo que a fé e a Palavra reinam diretamente na alma. A liberdade do cristão consiste, pois, na própria fé e somente nela.

Ter fé em Deus, de acordo com Lutero, significa crer Nele, acreditar em Sua Verdade e Justiça, o que constitui a maior honra que se pode prestar a Ele. Por outro lado, não acreditar em Deus, significa considerá-Lo "incapaz, mentiroso e leviano" (LUTERO, 1998, p. 36-7, § 11). É por isso que,

[...] ao ver que a alma reconhece Nele a verdade honrando-o por meio de sua fé, Deus, por sua vez, honra a alma e a considera justa e verdadeira (Ibidem).

Adiante, Lutero (1998, p. 37-39, § 12, grifo nosso) utiliza a metáfora do casamento da alma com Cristo para explicar o mecanismo pelo qual a fé liberta os homens do pecado, tornando suas almas livres, justas e bem-aventuradas:

Uma vez que Cristo é Deus e homem que jamais pecou, e sua justiça é invencível, eterna e onipotente, ao apropriar-se do pecado da alma crente por meio da aliança do casamento, isto é, a fé, ele age como se ele mesmo o tivesse cometido; por conseguinte, os pecados são tragados por ele e nele submergem. Já que a sua justiça invencível é mais forte que todos os pecados; portanto, a alma fica livre e liberta de todos os seus pecados, simplesmente mediante o seu dote, isto é, em virtude da fé, e munida da justiça eterna de Cristo, seu noivo.

Somente a fé é capaz de fazer a alma cumprir o primeiro e principal mandamento Honrarás a um só Deus (Êxodo 20:3 apud LUTERO, 1998, p. 39, § 13) - e, com isso, a alma cumpre facilmente todas as outras leis. É por isso que o reformador alemão qualifica como "perigoso e sinistro" o discurso de quem ensina cumprir os mandamentos com obras - como fazia a Igreja Católica Romana na época -, pois, sendo a única capaz de honrar Deus, "a fé do coração" é o "princípio e essência absoluta da justiça" (LUTERO, 1998, p. 39, § 9).

Lutero, contudo, não afirma que as obras são desprovidas de qualquer valor. Para ele, as obras têm uma função bastante específica, qual seja, a de mortificar o corpo, isto é, torná-lo livre dos prazeres carnais e da ociosidade 3 . O cristão, afirma Lutero no $§ 2$ de A liberdade do cristão, possui uma "natureza dupla": ele é um ser espiritual, mas também é um ser corporal. É esta dupla natureza de um ser que possui alma (homem espiritual, novo e interior) e também carne e sangue (homem corporal, velho e exterior)

\footnotetext{
${ }^{3}$ A sabedoria popular, com base na teologia luterana ou não, condena a ociosidade, considerando-a causa ou, ao menos, pretexto para a prática do mal: "cabeça vazia, oficina do diabo!".
} 
que coloca a necessidade das boas obras: é preciso subjugar o corpo. No entanto, o reformador alemão deixa claro que as obras não têm o poder de tornar o homem justo, pois alguém pode ser mau e, não obstante, realizar coisas que externamente reconhecemos como boas obras. Escreve Lutero (1998, p. 53-5, § 23):

Conforme afirma Cristo [Mt 7,18]: “Não pode a árvore boa dar maus frutos, nem a árvore má dar bons frutos". Está claro então que nem os frutos sustêm a árvore, nem a árvore cresce nos frutos, mas ao contrário: a árvore sustém os frutos e os frutos crescem na árvore. $\mathrm{E}$ a árvore, por sua vez, deve existir antes dos frutos. Estes não tornam a árvore nem boa, nem má; a árvore, porém, faz o fruto bom ou mau.

Nesse sentido, podemos afirmar que Lutero enfatiza o papel da intenção: é o aspecto interior que vai definir se uma obra é justa e boa, e não a obra por si mesma. Lutero, com efeito, não rejeita as boas obras por si mesmas. Ele apenas ressalta que "ninguém torna a pessoa boa, a não ser a fé; e ninguém a tornará má, a não ser a falta de fé" (1998, p. 57, § 24). Há, portanto, uma relação direta entre fé e bondade e entre ausência de fé e maldade, de modo que a fé constitui uma espécie de "lastro" para as boas obras. Em outras palavras, obras praticadas por pessoas que não têm fé só podem ser boas na aparência, de modo que, para o reformador alemão, essas pessoas não passam de "hipócritas", já que pretendem, de maneira deliberada, confundir e enganar a todos, como "lobos em pele de cordeiro". Desta maneira, Lutero (1998, p. 59, § 25) sintetiza a sua teoria da justificação:

Não se deve pregar apenas uma, mas ambas as Palavras de Deus. Deve-se pregar os mandamentos para intimidar os pecadores e revelar os seus pecados, levando-os ao arrependimento e à conversão. Mas isso não basta, é preciso pregar também a outra Palavra, a promessa da graça, ensinando a fé sem a qual os mandamentos, o arrependimento e tudo o mais será em vão [...] O homem, que por temor aos mandamentos de Deus se tem humilhado, atingindo assim o autoconhecimento, é justificado e elevado pela fé depositada nas palavras divinas.

Somente a fé pode salvar. Não obstante, praticar boas obras é importante para o cristão devido à sua natureza dupla (espiritual e corporal). Ao praticar desinteressadamente boas obras, o cristão subjuga seu corpo, de maneira a tirá-lo da ociosidade e, assim, controlar os seus impulsos. Além disso, Lutero (1998, p. 61, § 26) cita Paulo para lembrar que um cristão deve "servir e ser útil aos demais, visando unicamente às necessidades dos outros". Com efeito, um cristão deve praticar as boas obras não só como objetivo de mortificar o seu corpo, mas também para ajudar o próximo, visando o seu bem, "uma vez que cada qual com sua fé já possui o suficiente, e ainda lhe restam a vida e todas as outras obras para servir ao próximo com amor voluntário" (Ibidem). Lutero compara o amor ao próximo que o cristão deve cultivar ao amor de Cristo que, mesmo sendo livre e bem-aventurado, amou os homens e os ajudou em suas carências e necessidades para torná-los livres.

É justamente este amor ao próximo, articulado com a doutrina luterana da justificação por meio da fé, que vai fazer Lutero trazer à luz de sua teologia uma consequência eminentemente política. Lutero (1998, p. 65-7, § 28, grifo nosso) escreve que:

São Paulo também ordena em Rm [Romanos] 13 [1] e em Tt [Tito] 3 [1] aos cristãos a submeterem-se e disporem-se ao poder temporal, não porque assim se tornarão justos, mas para servirem voluntariamente aos outros e às autoridades fazendo-lhes a vontade com amor e liberdade. Quem entender isso poderá orientar-se em meio aos inúmeros mandamentos

\footnotetext{
${ }^{4}$ A citação que Lutero faz é da exortação de São Paulo aos Filipenses: “Exorto-vos em nome de todo o consolo que encontreis em Cristo, e de todo o consolo que encontreis em nosso amor por vós, e de toda comunhão que encontreis em meio a todos os cristãos justos e espirituais; completai a alegria em meu coração para que sintais o mesmo, tendo o mesmo amor pelos semelhantes, servindo-vos uns aos outros, e não atente cada um apenas para o que é seu, mas também para o que é dos outros, e para o que eles necessitam" (Filipenses 2:1-4 apud LUTERO, 1998, p. 61, § 26).
} 
e leis do papa, dos bispos, dos conventos, dos mosteiros, dos príncipes e dos senhores, as quais certos prelados tolos praticam como se fossem necessárias para a bem-aventurança, chamando-as erroneamente de mandamentos da Igreja. Porque um cristão livre diz: "Vou jejuar e orar, farei tudo o que for ordenado, mesmo sem precisar, não porque busco por meio disto tornar-me justo ou bem-aventurado, mas porque quero sofrer e prestar um serviço, servir de exemplo e fazer as vontades do papa, do bispo, da paróquia ou de meus irmãos na fé e de meu senhor. Do mesmo modo, Cristo sofreu e fez voluntariamente por mim coisas muito maiores, das quais necessitava bem menos que eu. E, embora os tiranos ajam injustamente ao exigirem tais coisas, isso em nada me prejudicará, desde que não vá contra Deus".

A dupla natureza do cristão faz com que ele pertença, a um só tempo, ao Reino de Deus, enquanto alma, e ao Reino do Mundo, enquanto corpo. O cristão deve obedecer à autoridade secular, desde que esta não vá contra Deus, pois obedecê-la significa servir voluntariamente ao próximo com amor e liberdade. Tal obediência, frisa Lutero, não conduz à salvação, posto que esta depende somente da fé na Palavra de Cristo. Desta maneira, Lutero faz sua crítica à Igreja Católica Romana tanto no que diz respeito à salvação por meio de obras e venda de indulgências, quanto no que se refere à tentativa da Igreja se apropriar do poder temporal, ao passo que, na opinião de Lutero, o poder espiritual deveria restringir-se ao espírito, ao Reino de Deus. É do que trataremos no tópico a seguir.

\section{A necessidade de reformar a igreja e o recurso à autoridade secular}

Para Lutero, a Igreja Católica Romana tornara-se corrupta ao levar a cabo um processo de secularização que visava, como aponta Skinner (1996, p. 294), dominar e dirigir a vida do cristão. A corrupção se expressava, sobretudo, no tráfico das indulgências ${ }^{5}$, motivo principal da indignação que levou Lutero a propor a Reforma da Igreja, pois as indulgências baseavam-se numa teologia mais ampla que fazia o papado, de modo particular, e a Igreja, de modo geral, ter o poder divino de fazer um pecador alcançar a salvação, o que, para Lutero, só era possível por meio da fé. $\mathrm{Na}$ tentativa de denunciar e acabar com a corrupção da Igreja, Lutero recorre ao poder temporal, exortando o imperador e os príncipes no seu Manifesto à nobreza cristã da nação alemã sobre o aprimoramento do estado cristão (1520).

Ao pedir auxílio do poder civil, Lutero acaba por questionar a relação entre a autoridade espiritual e a autoridade temporal que, "por meio exatamente das vicissitudes, haviam definido até então o mundo ocidental" (ASSOUN, 1993, p. 705). Tais vicissitudes resultavam da ausência de limites claros para esses poderes. Com efeito, HÖPFL (2005, p. IX-X) escreve que:

Tamanha era a interpenetração entre o secular e o espiritual no século XVI, que nenhuma reforma da religião poderia ser feita sem uma transformação da ordem pública nas unidades políticas da Europa cristã, e nenhuma mudança poderia ser institucionalizada sem a assistência dos governantes seculares.

\footnotetext{
${ }^{5} \mathrm{O}$ tráfico de indulgências foi uma das principais razões que levaram Lutero a escrever as suas Noventa e cinco teses pregadas na frente da Igreja de Wittenberg em 1517, ato que se converteu numa espécie de marco inicial da Reforma Protestante. Sua indignação provinha do fato de que qualquer um com dinheiro, não importando suas ações ou fé, poderia justificar-se perante Deus e livrar-se do inferno. Segundo SKINNER, as indulgências deviam "sua base teológica à bula Unigenitas, de 1343. Esse diploma dizia que os méritos que Cristo exibira ao sacrificar-se eram maiores do que o necessário para redimir toda a raça humana. Por isso, proclamava, a Igreja tinha o poder de conceder esses méritos adicionais vendendo indulgências (isto é, remissões de penitência) a quem confessasse haver pecado. A doutrina recebeu uma perigosa extensão com Sisto IV, afirmando, em 1476, que as almas no purgatório também poderiam ser socorridas ao se adquirir uma indulgência em seu favor" (1996, p. 294). É importante ressaltar que a indignação acerca das indulgências datava de antes de Lutero, mas foi com Lutero que essa indignação atingiu seu ponto máximo.
} 
Embora suas motivações para reformar a Igreja Católica Romana tivessem um caráter fundamentalmente religioso, Lutero precisava do apoio das autoridades seculares para levar a cabo tal Reforma e, por isso, envolveu-se diretamente com a política, o que fez seu Manifesto à nobreza cristã produzir, como afirma Assoun (1993, p. 705), um efeito subversivo. Com seu escrito, Lutero desejava:

[1] Persuadir o imperador e os príncipes da Alemanha para acabar com as trapaças e a riqueza e o poder secular fraudulentamente adquiridos pelo papado e pelo alto clero; [2] tenta também convencê-los a convocar um Concílio da Igreja; [3] a garantir a existência de sacerdotes casados, residentes nas paróquias onde deveriam pregar e exercer seu ministério; [4] a reformar os currículos de Filosofia e Teologia das universidades (onde os clérigos eram formados); e [5] a limitar drasticamente o número e o tamanho das ordens religiosas. (HÖPFL, 2005, p. X).

Mas a autoridade dos governantes seculares teria o direito de promover essas transformações e, assim, intervir de maneira profunda no Estado espiritual (encarnado na Igreja)? Lutero acreditava que sim. Para ele, os governantes seculares não deveriam temer os anátemas violentos de Roma - o próprio Lutero foi excomungado em 1521-, tampouco a exclusividade do direito à interpretação das Sagradas Escrituras, uma vez que "todo cristão é um membro do 'Estado espiritual', outorgado a julgar as doutrinas por si mesmo" (HÖPFL, 2005, p. XI). Para Lutero, as autoridades seculares, assim como qualquer cristão, tinham não só o direito como também o dever de não permitir a continuidade das atitudes tirânicas e corruptas da Igreja de Roma.

É preciso assinalar, contudo, que a cooperação estratégica com o poder temporal para realizar as transformações almejadas tinha o seu preço. Enquanto muitos governantes agiam com hostilidade à Reforma, a maioria dos que se mostravam simpáticos a ela exigiam ter o "direito de nomeação do clero e dos professores (dois ofícios correlatos) e, em geral, de supervisionar todos os aspectos de 'suas' Landeskirchen" (HÖPFL, 2005, p. XII). Estava em questão, portanto, a independência escolástica, um preço que podia se mostrar caro demais para ser pago. Assim, Lutero é levado a escrever o seu tratado Sobre a autoridade secular (1523), obra na qual ele vai expor os limites da autoridade secular e defender a autonomia para a Igreja Reformada.

Ao colocar nas mãos dos governantes seculares a tarefa da Reforma, o Manifesto à nobreza cristã da nação alemã trará como consequência o alargamento do campo de ação da autoridade secular ante a Igreja Romana, ou seja, ante a autoridade espiritual. Assim, em Sobre a autoridade secular, obra dedicada ao seu protetor - Frederico, o Sábio, Eleitor da Saxônia -, Lutero decide explicitar os limites de atuação dos governantes terrenos. No início desta última obra, ele conta:

\begin{abstract}
Algum tempo atrás, escrevi um panfleto dirigido à nobreza alemã. Nele, apontei suas tarefas e deveres como cristãos [...]. Assim, devo dirigir meus esforços em outra direção e escrever, em vez disso, acerca do que eles não devem fazer e do que devem cessar de fazer. Tenho certeza de que prestarão tão pouca atenção desta vez quanto fizeram em relação a meu último escrito. Que possam por muito tempo permanecer príncipes sem jamais se tornarem cristãos. Pois deus Todo-Poderoso tornou loucos os nossos príncipes: eles realmente acreditam que podem ordenar a seus súditos o que quer que desejem e fazer em relação a eles o que bem lhes aprouver. E seus súditos estão igualmente iludidos e acreditam (erroneamente) que devem obedecer-lhes em todas as coisas. (LUTERO, 2005, p. 5-6).
\end{abstract}

\footnotetext{
${ }^{6}$ De acordo com (HÖPFL, 2005, p. XI-XII), Lutero não tinha uma estratégia reformista muito clara. Tal fato, somado à diversidade de posições dos vários reformadores, fez com que a reforma seguisse rumos divergentes. A maioria dos reformadores não aceitava a colaboração com as autoridades seculares. Ao invés disso, eles queriam controlar a autoridade secular e formar, por si mesmos, congregações voluntárias e restritas: eram os partidários da Reforma Radical. Do outro lado, estavam os Reformados Magisteriais, como Lutero e Calvino, os quais visavam a uma reforma restrita a determinados territórios (Land) controlados por autoridades seculares favoráveis, formando assim a Igreja desse território: a Landeskirchen.
} 
Ao dizer o que o imperador e os príncipes não devem fazer, o reformador alemão vai estabelecer limites para a atuação da autoridade secular e não demonstra qualquer apreensão com as possíveis reações de determinados governantes seculares que, seguidores da Igreja de Roma, eram hostis à Reforma ${ }^{7}$. Porém, antes de delinear o campo de atuação da autoridade secular, Lutero precisa responder a questões anteriores: qual o fundamento da autoridade secular? Por que existem governantes seculares? É possível que os cristãos utilizem a autoridade secular de maneira benéfica?

\section{A autoridade secular: seu fundamento, seu papel e seus limites}

Para Lutero, a lei secular e a Espada - símbolo da autoridade secular que enfatiza a sua função repressiva, como veremos - só existem no mundo por causa da vontade e da providência divinas. Ele corrobora esta tese com várias passagens das Sagradas Escrituras, como em Romanos, 13: 1-2 (apud LUTERO, 2005, p. 8, grifo nosso) ${ }^{8}$ :

Todo homem se submeta ao poder e à superioridade. Pois não há poder que não venha de Deus. De modo que aquele que resiste ao poder opõe-se à ordem divina atrairá sobre si mesmo a condenação.

Lutero também cita Pedro I, 2: 13-14 (apud LUTERO, 2005, p. 8-9, grifo nosso):

Sujeitai-vos a toda sorte de ordenação humana, seja ao rei, como soberano, seja aos governadores, como enviados por ele, como uma vingança contra os malfeitores e uma recompensa para os justos.

Já que todo tipo de poder - incluindo o poder temporal - provém de Deus, então é preciso que se obedeça à autoridade secular, posto que resistir ao imperador, rei, príncipe ou governante significaria opor-se à vontade e à providência divinas. O fundamento da autoridade secular é, pois, o próprio Deus. Lutero não considera essa não-resistência ao poder como algo nocivo, pois a maneira pela qual Deus ordenou os homens, criando a autoridade secular, tem o objetivo de vingar os malfeitores e recompensar os justos. Em outras palavras, o poder secular representa a promoção da justiça entre os homens. Tal justiça não é, frisa Lutero, a justiça do próprio Deus, mas sim a justiça da Espada, a qual parte do princípio de que "quem derrama o sangue do homem, pelo homem terá seu sangue derramado" (Gênese 6 apud LUTERO, 2005, p. 9). Lutero explica que:

Isso [o trecho do Gênese] não pode ser interpretado como uma referência a [o próprio] Deus infligindo sofrimento e punição aos assassinos, uma vez que muitos deles, seja porque se arrependem, seja porque recebem perdão, permanecem vivos e morrem [naturalmente] sem a espada. Não: isso se refere à justiça da espada: um assassino perde o direito a sua vida, e é de justiça que ele seja morto pela espada [...]. É culpa dos homens se a lei de Deus não é levada a cabo, assim como se os demais mandamentos de Deus não são obedecidos.

Para Lutero (2005, p. 10), as Escrituras deixam claro que o emprego da Espada e da lei seculares é aprovado por Deus desde que elas sejam utilizadas conforme a Sua vontade, isto é, desde que elas sirvam "para punir os malfeitores e proteger

\footnotetext{
${ }^{7}$ De maneira ousada, Lutero (2005, p. 7-8) faz a seguinte afirmação também no início do Sobre a autoridade secular: "Devo resistir a eles, ainda que apenas com palavras. E uma vez que não tive temor de seu ídolo, o papa, quando me ameaçou com a perda do céu e de minha alma, devo mostrar ao mundo que tampouco tenho receio dos lacaios do papa, que me ameaçam [apenas] com a perda da minha vida e meus bens mundanos".

${ }^{8}$ O leitor notará que todas as citações da Bíblia são referenciadas ao próprio texto de Lutero. Optamos por assim fazê-lo porque utilizar outras traduções da Bíblia que não a feita pelo próprio Lutero poderia desorientar um pouco a nossa análise.
} 
os justos". Porém, em outros pontos da Escritura, é possível encontrar afirmações que parecem desaprovar o uso da Espada secular como instrumento para punir os malfeitores. Em um desses trechos citados por Lutero, Cristo afirma:

Ouvistes o que foi dito a vossos ancestrais: olho por olho, dente por dente. Eu, porém, vos digo: não resistais ao homem mau; antes àquele que te fere na face direita oferece-lhe também a esquerda; e àquele que quer pleitear contigo, para tomar-te a túnica, deixa-lhe também a veste; e se alguém te obriga a caminhar uma milha, anda com ele duas, etc. (Mateus 5: 38-39 apud LUTERO, 2005, p. 10-11).

O reformador alemão explica que esta aparente contradição é utilizada por sofistas $^{9}$ para dizerem que Cristo aboliu a lei mosaica. Assim, as leis expressas por Moisés só deveriam ser aplicadas para os homens imperfeitos, ao passo que, para os perfeitos, os mandamentos seriam apenas conselhos de perfeição. Lutero repudia completamente essa divisão da doutrina e da condição cristãs, pois ele considera que a perfeição diz respeito à fé e ao amor. As obras e a condição exterior nada contribuem para tornar alguém mais perfeito, pois só é perfeito "todo aquele que acredita mais [firmemente] e tem mais amor", de sorte que "o amor e a fé não criam dissensões e distinções exteriores" (LUTERO, 2005, p. 11-12). Com efeito, Lutero considera que a única distinção relevante entre os homens é a que distingue os cristãos (pertencentes ao Reino de Deus) dos não-cristãos (pertencentes ao Reino do Mundo).

Quem são os cristãos? São aqueles que acreditam verdadeiramente em Cristo, seu rei e senhor. Cristo fora enviado para estabelecer o Reino de Deus, porém tal reino não é deste mundo. Por pertencerem ao Reino de Deus, os verdadeiros cristãos não têm nenhuma necessidade da Lei ou da Espada seculares, pois eles

[...] têm o Espírito Santo em seus corações, que os ensina e os leva a amar todas as pessoas, a não tratar ninguém de modo injusto e a suportar prazenteiramente as injúrias, até mesmo a morte (LUTERO, 2005, p. 12).

Os verdadeiros cristãos sempre agem de forma justa e reta, de modo que, por si mesmos, não têm necessidade de lei alguma. A lei existe por causa dos injustos, os não-cristãos pertencentes ao Reino do Mundo.

Lutero (2005, p. 14) lembra que ninguém nasce cristão:

Uma vez, porém, que nenhum homem é por natureza um cristão ou um justo, mas são todos maus e pecadores, Deus coloca obstáculos diante de todos eles, por meio da lei, impedindo-os de fazer o que querem e de expressar exteriormente, em ações, a sua iniquidade.

A função da Lei é, portanto, impedir a expressão exterior da iniquidade humana e, ao fazê-lo, ensina como reconhecer um pecado, de modo a rebaixar "o homem no sentido da disposição de aceitar a graça e a fé em Cristo" (Ibidem). Nas palavras do próprio Lutero (2005, p. 15), eis a importância da autoridade secular:

Se não existissem [leis e governos], uma vez que o mundo é mau e apenas um ser humano em mil é um verdadeiro cristão, as pessoas se destruiriam umas às outras e ninguém seria capaz de sustentar sua mulher e seus filhos, de se alimentar e de servir a Deus. O mundo tornar-se-ia um deserto. E assim Deus instituiu os dois governos, o [governo espiritual], que molda os verdadeiros cristãos e as pessoas justas por meio do Espírito Santo sob Cristo, e o governo secular, que reprime os maus e os não-cristãos e os obriga a conservarem-se exteriormente em paz e a permanecerem quietos, gostem ou não disso.

Para Lutero, o papel da autoridade secular resume-se basicamente ao exercício de sua função repressiva para punir os injustos e, assim, proteger os justos, de modo a manter a paz social. Com efeito, pode-se afirmar que a autoridade secular

\footnotetext{
${ }^{9}$ Neste contexto, Lutero utiliza o termo "sofista" provavelmente para designar de forma pejorativa - e anônima, já que ele não cita diretamente nenhum nome - os teólogos que defendem opiniões das quais ele não só discorda como também repudia.
} 
é, fundamentalmente, a Espada. Se todos os homens fossem bons, então não seria necessário que Deus instituísse a autoridade secular, já que todos viveriam conforme o Evangelho, como bons cristãos. Entretanto, o homem é um ser corrompido, de modo que poucos deles são verdadeiros cristãos. É por isso que Lutero (2005, p. 16-17) qualifica como loucura a tentativa de alguns reformadores em governar todos os homens, os justos e os injustos, apenas com base no Evangelho. Ele explica que:

Tentar governar toda uma região ou mesmo o mundo inteiro por meio do Evangelho é como abrigar no mesmo aprisco lobos, leões, águias e carneiros, permitindo que se associem livremente, e dizer-lhes: alimentem-se e sejam justos e pacíficos; o estábulo não está fechado, existe pastagem em abundância lá fora e não há cães ou porretes que precisem temer. Os carneiros certamente conservar-se-iam em paz e se deixariam ser governados e alimentados sossegadamente, mas não sobreviveriam por muito tempo.

Fica claro, portanto, que a existência dos dois governos - o espiritual e o temporal ou secular - se faz necessária. O governo espiritual e o governo secular apresentam, sob esse aspecto, uma relação de interdependência ou, se quiser, de complementaridade: sem o governo espiritual, os homens jamais conseguiriam alcançar a salvação; por outro lado, sem o governo secular, a iniquidade humana prevaleceria (LUTERO, 2005, p. 17-18). Assim, é possível compreender o contexto em que Cristo fala em "dar a outra face": Cristo governa os cristãos através do Espírito Santo, e não por meio de leis ou da Espada. Ele não aboliu a lei mosaica: simplesmente não a empregou, "pois ela não favorece o seu reino, que não contém senão os justos" (LUTERO, 2005, p. 18-19). Desta forma, Lutero refuta os sofistas.

Mas se os cristãos não necessitam da Espada, já que pertencem ao Reino de Deus, o qual é governado por Cristo, por que eles devem sujeitar-se a ela, como Paulo coloca na Epístola aos Romanos ("Todo homem [cristão ou não] se submeta ao poder e à superioridade")? Lutero vai apresentar duas justificativas para isso, uma de caráter teológico e outra de caráter que podemos definir como pragmático.

(1) Justificativa teológica: os cristãos devem se submeter à autoridade temporal, pagando impostos e servindo de sustentáculo para o poder secular (LUTERO, 2005, p. 20), porque eles, enquanto verdadeiros cristãos, devem servir ao próximo. Assim, mesmo que a lei e a Espada não os beneficiem, eles devem submeter-se a elas com o objetivo de proteger o seu próximo dos malfeitores. É por isso Lutero (2005, p. 21) interpreta:

[O próprio Cristo] Não os proíbe [os cristãos] de servirem e de se submeterem àqueles que de fato detêm a Espada secular e as leis. Ao contrário, precisamente porque vocês [que são cristãos] não necessitam dela e não devem tê-la, devem servir àqueles que não alcançaram o mesmo nível [espiritual] em que vocês se encontram e que ainda necessitam dela. Embora vocês próprios não precisem de que seu inimigo seja punido, seu vizinho vulnerável precisa, e vocês devem ajudá-lo a gozar de tranquilidade e tratar de fazer com que os inimigos sejam reprimidos.

(2) Justificativa pragmática: Se os cristãos não fossem submissos à autoridade temporal, eles dariam um mau exemplo aos não-cristãos, os quais teriam um motivo para não cumprir as leis. Tal fato daria

[...] má reputação ao Evangelho, como se ele pregasse a rebelião e produzisse pessoas egoístas, sem vontade de ser úteis e prestimosas aos demais, ao passo que o Evangelho faz do cristão alguém devotado a todos (LUTERO, 2005, p. 21).

O reformador alemão lembra Mateus 17: 24-27: “Cristo pagou o tributo para não provocar escândalo, embora não tivesse necessidade de fazê-lo" (Ibidem).

Tal justificativa reitera a necessidade de ajudar o próximo a ficar livre dos malfeitores e, nesse sentido, resulta profundamente da convicção teológica do reformador alemão. Há, contudo, uma implicação política: ao dizer que o Evangelho pode ganhar má 
reputação caso ele seja utilizado para fundamentar rebeliões e, assim, promover certa resistência à autoridade secular por parte dos cristãos, Lutero já indica sua posição contrária às revoltas camponesas e todo tipo de violência pela qual a palavra de Deus é invocada para derrubar governantes. Com efeito, em 1525, por ocasião da revolta dos camponeses liderada por Thomas Müntzer, que se desencadeou na Alemanha, Lutero vai escrever o seu manifesto Contra os bandos saqueadores e mortíferos dos camponeses.

A preocupação de Lutero era que houvesse um curto-circuito entre espírito e mundo, isto é, entre reforma religiosa e reforma social, de modo que os governantes, vendo seu poder ameaçado, se voltassem cada vez mais contra a reforma religiosa que Lutero almejava realizar (Cf. ASSOUN, 1993, p. 707-709). Contudo, como verifica Skinner, na década de 1530, Lutero mudará sua posição sobre isso ao ver os exércitos do Império esmagar a Igreja Luterana (1996, p. 300).

Apesar disso, o essencial é que com estas duas justificativas, Lutero defende que os cristãos cooperem com a autoridade secular, ocupando cargos inclusive, pois já que todo o poder vem de Deus, ele pode e deve ser utilizado para servir a Deus. E ninguém pode ser melhor servo de Deus do que o cristão (Cf. LUTERO, 2005, p. 27-28). Para o reformador alemão, os cristãos podem ser advogados, juristas e até mesmo carrascos:

[...] se o governo e a Espada servem a Deus [...] então tudo de que o governo necessita para empunhar a espada constitui igualmente um serviço a Deus. Tem de haver alguém encarregado de capturar os maus, acusá-los e executá-los, e de proteger, inocentar, defender e salvar os homens bons. (LUTERO, 2005, p. 33).

Os cristãos são, portanto, uma peça-chave para que a autoridade secular consiga trabalhar no sentido de promover a justiça e a paz social entre os homens. Para desempenhar bem este papel, a autoridade secular não pode ultrapassar certos limites, isto é, ela não pode invadir o governo e o Reino de Deus. Como vimos, o Reino de Deus, que fora instituído por Cristo, não é deste mundo: ele é espiritual, interior, ou seja, diz respeito à alma dos homens, e não ao seu corpo. Para não ultrapassar o seu âmbito de atuação, a autoridade secular não deve legislar sobre a alma. Ela deve, pelo contrário, restringir-se ao corpo dos homens, que é o único locus no qual a força da Espada pode fazer sentir-se. Lutero (2005, p. 35-36) escreve que

A experiência cotidiana mostra-nos suficientemente que cada reino deve ter suas próprias leis e que nenhum reino ou governo pode sobreviver sem lei. O governo secular tem leis que não se estendem além do corpo, dos bens e das questões exteriores, terrenas. Todavia, no que diz respeito à alma, Deus não pode e não quer permitir que nenhum outro governe além dele mesmo. E assim, onde a autoridade secular toma a seu cargo legislar em relação à alma, ela invade [o que pertence a] o governo de Deus e simplesmente seduz e faz perder as almas.

Para Lutero, apenas a Palavra de Deus pode direcionar as almas rumo à salvação. Aqui, o reformador alemão retoma com força a sua doutrina da justificação apenas pela fé (seu solifideísmo) e critica abertamente a tentativa da Igreja Católica Romana de impor certas crenças, de modo a abusar de sua função e de seu poder temporal conquistado de maneira ilegítima:

[...] é absoluta loucura eles [os governantes seculares] nos ordenarem que acreditemos na Igreja, nos Padres e nos Concílios mesmos que não exista Palavra [expressa] de Deus (LUTERO, 2005, p. 37).

Para Lutero, a verdadeira Igreja "não exige nada, à exceção do que é certo segundo a palavra de Deus" (Ibidem).

Isso ocorre porque a Igreja, enquanto representante da autoridade espiritual, deveria ser apenas uma congregação, um mero espaço de reunião para os cristãos, os quais já participariam da verdadeira Igreja, a saber, a Igreja invisível, puramente 
espiritual: o próprio cristão deve ler diretamente as Escrituras e buscar a sua salvação. A imposição pela Igreja de Roma de crenças que nada têm a ver com a Palavra de Deus e sua ratificação pelos governantes seculares é, na perspectiva de Lutero, uma tentativa clara de a autoridade secular legislar sobre a alma e, assim, ultrapassar sua esfera de atuação, que é o Reino do Mundo. Tal atitude é problemática porque, como explica Lutero (2005, p. 39):

Toda e qualquer autoridade só pode agir, e só deveria agir, onde possa perceber, saber, julgar, sentenciar e modificar as coisas [...]. Um tribunal deve ter um conhecimento exato do que deve julgar, mas os pensamentos e as mentes das pessoas não podem ser manifestos para ninguém à exceção de Deus. Portanto, é impossível e fútil ordenar ou coagir alguém a acreditar nisso ou naquilo. Exige-se aqui uma habilidade diretamente; a força não vai funcionar.

A habilidade da autoridade secular é a força, a Espada. Esta, contudo, não tem a capacidade de mudar as opiniões, ideias ou crenças de quem quer que seja. Ao tentar legislar sobre a alma, a autoridade secular vai, no máximo, impedir que as pessoas expressem por atos e palavras o que têm no interior de suas consciências: ao invés de dizerem o que pensam e acreditam, as pessoas vão simplesmente mentir e fazer juras em falso. Desse modo, Lutero (2005, p. 40, grifo nosso) faz uma defesa da liberdade de crença e da tolerância religiosa:

O modo como a pessoa acredita é um assunto de cada consciência individual, e isso não diminui [a autoridade de] os governantes seculares. Eles deveriam, portanto, contentar-se em cuidar de seus próprios assuntos e permitir que as pessoas acreditem no que podem e no que desejam, sem usar de coerção nessa esfera contra ninguém. A fé élivre, e ninguém pode ser compelido a crer.

Já que as tentativas de a autoridade secular fazer as pessoas acreditarem nisso ou naquilo são inúteis, Lutero defende que os governantes seculares deveriam parar de ameaçar com seu gládio as pessoas para fazê-las crer naquilo que, do fundo do coração, não acreditam. A obediência à autoridade secular diz respeito apenas aos bens exteriores. No que tange ao interior, isto é, à alma, todas as pessoas são livres da "jurisdição" da autoridade secular. Daí Cristo afirmar "devolvei ao imperador o que é do imperador, e a Deus o que é de Deus" (Mateus 22:21 apud LUTERO, 2005, p. 44).

\section{Considerações finais}

Com base em sua teologia, Lutero faz uma separação entre as esferas espiritual e temporal, entre o Reino de Deus e o Reino do Mundo. Tal distinção tem objetivo de atingir, sobretudo, o ímpeto da Igreja Católica Romana em conquistar cada vez mais poder secular, de maneira a tornar-se, na perspectiva de Lutero, cada vez mais corrupta e desviar os homens do verdadeiro caminho da salvação. Ainda que o estado espiritual possa ser considerado o fim último ao qual todo cristão almeja e seja ele que defina os limites da autoridade secular, é preciso levar em conta que, ao buscar reformar a Igreja, Lutero amplia imensamente o campo de ação da autoridade secular. Em outras palavras, ao reduzir a atuação da Igreja visível e mostrar que a salvação depende apenas da fé de cada um, o reformador alemão tira inúmeros poderes terrenos adquiridos ilegalmente pela Igreja Católica e os repassa à autoridade secular.

Desta maneira, Lutero deixa claro que a política é, por natureza, uma ocupação temporal, convicção que explicita a relação existente entre a autoridade espiritual e a autoridade secular: o (Reino do) mundo só existe por causa e em função do Reino de Deus - fato que evidencia a preocupação maior de Lutero, qual seja, a possibilidade da salvação. A autoridade secular é útil apenas na medida em pode contribuir para 
a ascensão ao Reino de Deus. Nesse sentido, pode-se afirmar que, para Lutero, a autoridade temporal subordina-se à autoridade espiritual. Sem o Reino de Deus, o (Reino do) mundo não teria sua razão de ser.

Correspondência: Renato de Oliveira Pereira. Universidade Estadual Paulista - UNESP, Av. Hygino Muzzi Filho, 737, Mirante, CEP 17525-000, Marília, SP, Brasil. E-mail: renato.o.pereira@hotmail.com

Conflito de interesses: Nenhum.

Todos os autores leram e aprovam a versão final submetida a revista Em curso. 


\section{Bibliografia}

ASSOUN, P. L. Lutero. In: CHATELET, F.; DUHAMEL, O.; PISIER, E. (org.). Dicionário das obras políticas. Tradução de Glória de C. Lins e Manoel Ferreira Paulino. Rio de Janeiro: Civilização Brasileira, 1993. p. 705-710.

HÖPFL, H. Introdução ao tratado sobre a autoridade secular de Lutero. In: LUTERO, M. Sobre a autoridade secular. Tradução de Hélio de Marco Leite de Barros e Carlos Eduardo Silveira Matos. 2. ed. São Paulo: Martins Fontes, 2005. p. 9-73.

LUTERO, M. Da liberdade do cristão: prefácios à Bíblia. Tradução de Erlon José Paschoal. São Paulo: Editora UNESP, 1998.

LUTERO, M. Sobre a Autoridade Secular. Tradução de Hélio de Marco Leite de Barros e Carlos Eduardo Silveira Matos. 2. ed. São Paulo: Martins Fontes, 2005.

SKINNER, Q. As Fundações do Pensamento Político Moderno. Tradução de Renato Janine Ribeiro e Laura Teixeira Motta. São Paulo: Companhia das Letras, 1996. 